\title{
Defensive Impact of Foliar Applied Potassium Nitrate on Growth Linked with Improved Physiological and Antioxidative Activities in Sunflower (Helianthus annuus L.) Hybrids Grown under Salinity Stress
}

\author{
Anisa Aslam ${ }^{1}$, Shahbaz Khan 2,*(D), Danish Ibrar ${ }^{2} \mathbb{D}$, Sohail Irshad ${ }^{3}$, Ali Bakhsh ${ }^{4}$, Syed Tahir Raza Gardezi ${ }^{5}$, \\ Madad Ali ${ }^{6}$, Zuhair Hasnain ${ }^{7}$ (D), Abdulrahman Al-Hashimi ${ }^{8}\left(\mathbb{D}\right.$, Mehmood Ali Noor $^{9}$, Marian Brestic ${ }^{10,11}$ (D), \\ Milan Skalicky ${ }^{11}$ iD and Ali Tan Kee Zuan ${ }^{12, *(D)}$
}

check for

updates

Citation: Aslam, A.; Khan, S.; Ibrar,

D.; Irshad, S.; Bakhsh, A.; Gardezi,

S.T.R.; Ali, M.; Hasnain, Z.;

Al-Hashimi, A.; Noor, M.A.; et al.

Defensive Impact of Foliar Applied

Potassium Nitrate on Growth Linked

with Improved Physiological and

Antioxidative Activities in Sunflower

(Helianthus annuus L.) Hybrids Grown under Salinity Stress. Agronomy 2021, 11, 2076. https://doi.org/10.3390/ agronomy11102076

Academic Editors: Manuel

Nieves-Cordones and

Francisco Rubio

Received: 18 September 2021

Accepted: 14 October 2021

Published: 17 October 2021

Publisher's Note: MDPI stays neutral with regard to jurisdictional claims in published maps and institutional affiliations.

Copyright: (c) 2021 by the authors. Licensee MDPI, Basel, Switzerland. This article is an open access article distributed under the terms and conditions of the Creative Commons Attribution (CC BY) license (https:// creativecommons.org/licenses/by/ $4.0 /)$.
Department of Botany, University of Agriculture, Faisalabad 38040, Pakistan; skbuaf@gmail.com National Agricultural Research Centre, Islamabad 45500, Pakistan; danish.uaar@gmail.com Department of Agronomy, MNS-University of Agriculture, Multan 64200, Pakistan; sohailuaf99@gmail.com

4 Department of Plant Breeding and Genetics, Ghazi University, Dera Ghazi Khan 32200, Pakistan; bkali_33@hotmail.com

5 Department of Agronomy, Bahauddin Zakariya University, Multan 60800, Pakistan; tahir.gardezi@agroinn.net

6 Department of Plant Breeding and Genetics, University of Agriculture, Faisalabad 38040, Pakistan; 2017ag137@pern.onmicrosoft.com

7 Department of Agronomy, PMA-Shah Arid Agriculture University, Rawalpindi 46000, Pakistan; zuhair@uaar.edu.pk

8 Department of Botany and Microbiology, College of Science, King Saud University, P.O. Box 2455, Riyadh 12 11451, Saudi Arabia; aalhashimi@ksu.edu.sa

9 Chinese Academy of Agricultural Sciences, Beijing 100081, China; mehmood2017@gmail.com

10 Institut of Plant and Environmental Sciences, Slovak University of Agriculture, 94976 Nitra, Slovakia; marian.brestic@uniag.sk

11 Department of Botany and Plant Physiology, Faculty of Agrobiology, Food and Natural Resources, Czech University of Life Sciences, 16500 Prague, Czech Republic; skalicky@af.czu.cz

12 Department of Land Management, Faculty of Agriculture, University Putra Malaysia, UPM Serdang, Seri Kembangan 43400, Selangor, Malaysia

* Correspondence: shahbaz2255@gmail.com (S.K.); tkz@upm.edu.my (A.T.K.Z.)

\begin{abstract}
Salt stress is recognized to negatively influence the fundamental processes in plants regarding growth and yield. The sunflower (Helianthus annuus L.) is considered an important industrial crop because of the good quality of oil it produces that can be used for cooking purposes. The exogenous application of potassium $(\mathrm{K})$ has been reported to enhance abiotic resistance and increase yield in crops. Here, we explored the impact of foliar-applied $\mathrm{K}$ at $500 \mathrm{ppm}$ on the physiological and biochemical traits, antioxidant activities, and growth attributes of sunflower grown under salt stress $(140 \mathrm{mM} \mathrm{NaCl})$. The findings indicated that salinity stress adversely affected photosynthesis and various gas exchange characteristics. Foliar applied $\mathrm{K}$ markedly improved the stomatal conductance, transpiration rate, water use efficiency, $\mathrm{CO}_{2}$ assimilation rate, total soluble proteins, chlorophyll pigments, and upregulated antioxidant system, which are responsible for the healthy growth of sunflower hybrids grown under salinity stress. The shoot and root lengths, plant fresh and dry weights, and achene weight were significantly increased by K application. Overall, foliar applied $\mathrm{K}$ significantly improved all of the aforementioned attributes and can attenuate the deleterious influences of salinity stress in sunflower.
\end{abstract}

Keywords: achene; catalase; growth; hybrid; phenolic; stress

\section{Introduction}

The intensification of crop production in semi-arid regions of the world requires vigorous and healthy crop growth and establishment in order to overcome the adverse effects 
of abiotic stresses, particularly salinity. Salinity is a gigantic issue for agricultural crops. It causes nutrient imbalance and cell injuries due to the accumulation of sodium $\left(\mathrm{Na}^{+}\right)$and chloride $\left(\mathrm{Cl}^{-}\right)$ions, which is the reason for the low yield under soil salinities [1,2]. Salt stress generates destabilization in the uptake, transport, and distribution of nutrients in crops, which can effectuate physiological processes, and thus decreases growth [3]. An antagonistic relation exists between $\mathrm{K}^{+}$and $\mathrm{Na}^{+}$in soil because $\mathrm{NaCl}$ reduces the potassium (K) concentration in the shoots and roots [4]. Abiotic stresses like salinity and drought create osmotic stress [5], reactive oxygen species (ROS) [6], and cause oxidative damage in plant cells [7], which ultimately affect the growth and productivity of crops [8]. Osmotic and oxidative stresses lead to several physiological changes, including a decrease in photosynthetic activities [9], DNA, protein and membrane damages, and nutritional imbalance in plants $[10,11]$. Salt stress damages the chloroplast ultrastructure and photosynthetic characters, which ultimately reduce the yield [12]. Growth attributes like shoot length, stem diameter, number of leaves, and shoot fresh and dry weights are adversely affected under salinity stress [13].

One of the valuable macronutrients, $\mathrm{K}$, triggers plant growth and development under normal and stressed environments. It decreases the transpiration rate and enhances the water uptake, and thus the yield becomes good. It also prolongs the turgidity, and reduces the adverse effect of reactive oxygen species (ROS) [14]. The foliar application of $1 \% \mathrm{~K}$ significantly increased the plant height, as well as the morphological and physiological parameters [15]. $\mathrm{K}^{+}$is the most common nutrient in the triad group including $\mathrm{N}$ and $\mathrm{K} . \mathrm{K}^{+}$is well known for accelerating the enzymatic activity and speeds up enzymatic metabolism [16]. Even though the literature points out that the exogenous application of $\mathrm{K}$ has a positive effect on sunflower productivity. Hence, $\mathrm{K}$ plays its role in improving the physiological system and antioxidant defense mechanisms [17]. Supplemental K and chitosan improve the growth and quality of sunflower through regulating the leaf turgor and antioxidant metabolism, as well as reducing the effect of salinity [18]. The macronutrient $\mathrm{K}$ has a primary function in plants comprising the enhancement of tolerance to deterrent stresses. Each nutrient can affect plant chlorophyll, carotenoids, and plant length, depending on its biochemical properties [19]. It must be reported $\mathrm{K}$ affects the alleviation of stress on sunflower; thus, increasing the rate of plant proteins that can regulate diverse plant activities under stress. The foliar application of $1 \% \mathrm{~K}$ significantly increased the plant height, as well as the morphological and physiological parameters of sunflower. Higher oil production, including of unsaturated fatty acids, was also observed after the foliar application of $\mathrm{K}$ at a $1 \%$ solution [15]. Furthermore, it increases the production of proline, which can perk up plant tolerance under any stress by osmotic adjustment [20].

Sunflower (Helianthus annuus L.) is one of the most essential oil crops in the world and is ranked second after soybean [21]. The main advantage of this crop is its high oil content, making up $42-50 \%$ of seed weight and having a $15-20 \%$ protein content. Its oil is composed of more than $90 \%$ unsaturated fatty acids, such as linoleic (18:2) and oleic (18:1) acids, which have cost of living benefits [22]. Sunflower contributes significantly to the oil needs of Pakistan [23]. Moreover, cultured sunflower shows genotypic substitution in response to abiotic stresses [24]. Stress critically influences the sunflower yield through nutritional imbalance. To mitigate the nutrient imbalance and osmotic stress imposed by soil salinity, sunflowers use mechanisms to reduce water loss while maximizing water uptake, including a reduction in the leaf area and osmotic adjustment [25] through the application of minerals [26], liquid seaweed extract [27], and organic compounds [28]. The foliar spray approach is more applicable regarding nutrient availability for optimum development and growth, and an improved quality of field crops cultivated under unfavorable environments [29-32]. Developing more stress tolerant crops requires greater knowledge of the physiological basis of stress tolerance [33]. Therefore, the current study was designed with the following objectives: (i) to observe the response of salinity stress on the physiology and growth of two sunflower hybrids, L-16003 and L-Chek1, and (ii) to explore the impact of the foliar spray of $\mathrm{KNO}_{3}$ in sunflower as a protectant against salinity stress. 


\section{Materials and Methods}

\subsection{Experimental Details}

A pot experiment was conducted to cope with the salinity stress in sunflower through the foliar application of $\mathrm{K}$ under greenhouse conditions at the Old Botanical Garden, University of Agriculture, Faisalabad, Pakistan. This experiment was conducted in a completely randomized design (CRD) with a factorial arrangement having three replicates. The seeds of sunflower hybrid L-16003 and L-Check 1 were purchased from Punjab Seed Corporation, Faisalabad, Pakistan. Plastic pots, $30 \mathrm{~cm}$ in height and $22 \mathrm{~cm}$ in diameter, were filled with growth media, with $5 \mathrm{~kg}$ in each pot. The growth media consisted of compost, clay, silt, and sand in equal proportions. Four seeds were sown in each pot and the pots were placed in a greenhouse. After 15 days of emergence, thinning was done to maintain a single plant in each pot for further experimentation. Pots were divided into main groups according to fresh irrigation water $(4 \mathrm{mM} \mathrm{NaCl})$ and saline solution $(140 \mathrm{mM} \mathrm{NaCl})$. Pots were irrigated at field capacity (FC), and FC was maintained up until harvesting of the plants, starting from the sowing. In order to determine the water loss by transpiration, the pots were weighed on daily basis and the soil moisture contents were sustained by recompensing this water loss through the addition of tap water up to the initial weight of the respective pot. The gravimetric method, described by Nachabe [34], was followed to determine the FC. Only once throughout the course of experimentation, salinity treatment of $140 \mathrm{mM} \mathrm{NaCl}$ was applied (at three leaf stage) to compare the fresh water irrigation and be used as a control. Initially, $150 \mathrm{~mL}$ of water was required for FC as each pot contained $5 \mathrm{~kg}$ of growth media. Then, $8.775 \mathrm{~g}$ of $\mathrm{NaCl}$ was dissolved in $150 \mathrm{~mL}$ of water to prepare a $140 \mathrm{mM}$ solution of $\mathrm{NaCl}$, as the $\mathrm{NaCl}$ molar mass is 58.5 . After that, the pots were irrigated with fresh water. The first round of foliar spray of $\mathrm{KNO}_{3}$ at a $500 \mathrm{ppm}$ concentration was applied after one week of imposition of salinity treatment. During experimentation, $\mathrm{KNO}_{3}$ was applied three times with an interval of one week after the application of the first round. According to the water requirements of the crop, the pots were irrigation throughout the course of experimentation. Water spray was also considered as a control treatment.

\subsection{Biochemical, Mineral, and Antioxidant Enzyme Activity Measurement}

The data regarding biochemical and antioxidant activities were recorded after 5 days of the third round of treatment application. Chlorophyll $a(663 \mathrm{~nm})$ and $b(645 \mathrm{~nm})$ contents and carotenoids $(470 \mathrm{~nm}$ ) were measured through the extraction of leaves in an $80 \%$ solution of acetone, according to Arnon [35], by using Spectrophotometer with the following formula

$$
\begin{gathered}
\text { Chlorophyll } \mathrm{a}=[12.7(\mathrm{OD} 663)-2.69(\mathrm{OD} 645) \times \mathrm{V} / 1000 \times \mathrm{W} \\
\text { Chlorophyll } \mathrm{b}=[12.7(\mathrm{OD} 645)-4.68(\mathrm{OD} 663) \times \mathrm{V} / 1000 \times \mathrm{W} \\
\text { Carotenoids }=[\mathrm{OD} 470+0.114(\mathrm{OD} 663)-0.638(\mathrm{OD} 645) / 2500] \times 1000
\end{gathered}
$$

where $\mathrm{V}$ is the volume of the extract $(\mathrm{mL})$ and $\mathrm{W}$ is the weight of the fresh leaf $(\mathrm{g})$.

Soluble phenolics were determined by Julkunen-Titto's method [36]. A $0.1 \mathrm{~g}$ plant sample was extracted in $1 \mathrm{~mL}$ acetone (80\%). After centrifugation for $15 \mathrm{~min}$ at 12,000 rpm, the supernatant was collected in microfuge tubes and stored at $-30{ }^{\circ} \mathrm{C}$ until it was used. In a test tube, $100 \mu \mathrm{L}$ supernatant (diluted it up to $1 \mathrm{~mL}$ ), $0.5 \mathrm{~mL}$ of folin phenol reagent (Fluka), and $2.5 \mathrm{~mL}$ of $20 \%$ sodium carbonate $\left(\mathrm{Na}_{2} \mathrm{CO}_{3}\right)$ were added and made the volume up to $5 \mathrm{~mL}$. Then, the reaction mixture was vortexed for 5-10 s and kept for $20 \mathrm{~min}$ at room temperature. The absorbance of the colored complex was noted at $750 \mathrm{~nm}$, and $80 \%$ acetone was used as a blank.

The $\mathrm{Na}^{+}, \mathrm{K}^{+}$, and $\mathrm{Ca}^{2+}$ concentrations were meacured using a flame photometer (Sherwood, UK, Model 360) according to the standard procedure of the USDA Laboratory Staff [37]. The activities of the peroxidase (POD) and catalase (CAT) readings were noted on a spectrophotometer by the procedure of Chance and Maehly [38]. The Bradford technique [39] was used to determine the total soluble protein. For the measurement of 
the gas exchange features, the flag leaf was used during 10:00 a.m. to 12:00 p.m. Stomatal conductance $(g s)\left(\mu \mathrm{mol} \mathrm{m} \mathrm{m}^{-2} \mathrm{~s}^{-1}\right)$ and transpiration rate $(E)\left(\mu \mathrm{mol} \mathrm{m}{ }^{-2} \mathrm{~s}^{-1}\right)$, as well as the $\mathrm{CO}_{2}$ assimilation rate $(A)\left(\mu \mathrm{mol} \mathrm{m} \mathrm{m}^{-2} \mathrm{~s}^{-1}\right)$, were estimated according to the procedure described by Long [40], using an infrared gas analyzer (IRGA) LI-6400 portable device. Water use efficeiency (WUE) was calculated by dividing the $A$ with $E(A / E)$. The rate of water loss and rate of $\mathrm{CO}_{2}$ uptake were used to assess the rate of transpiration and photosynthetic carbon assimilation, respectively, using a working principle of LI-6400.

\subsection{Growth Attributes}

The number of leaves plant ${ }^{-1}$ were calculated manually. The formula to calculate the leaf area $\left(\mathrm{cm}^{2}\right)$ was as follows:

$$
\text { Leaf area }=\text { leaf width } \times \text { leaf length } \times \text { correction factor }(0.75)
$$

The leaf width and length were measured manually. The leaf length was considered from the leaf base to the tip of the leaf and the width was the maximum broad portion. The shoot $(\mathrm{cm})$ and root $(\mathrm{cm})$ lengths of the sunflower plants were measured with the help of a meter rod, and the mean values were calculated. The shoot was considered from the base to the top of the plant. Similarly, the root was considered from base (underground portion) to the tip of the root/root hairs. The achene weight was measured by electric weigh balance. The fresh weights of the roots $(\mathrm{g})$ and shoots $(\mathrm{g})$ were measured with an electric weigh balance and the sum for the plant fresh weight and dry weight were calculated. The roots and shoots were dried in sunlight for 3 days after this and were kept in the oven at a temperature of $65{ }^{\circ} \mathrm{C}$ until reaching a constant weight.

\subsection{Statistical Analysis}

For each parameter, ANOVA was applied to the data, which were organized in a completely randomized design (CRD) [41]. Co-Stat V6.3 computer software (Cohort software, Berkeley, CA, USA) was used for the data analysis. Microsoft Excel was used for the graphical presentation.

\section{Results}

\subsection{Growth Attributes}

The growth parameters of the sunflower hybrids were significantly affected by the foliar application of K grown under normal and saline conditions (Table 1). Sunflower

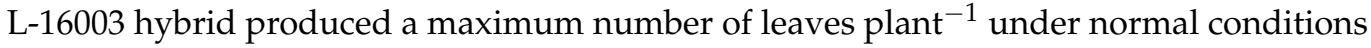
where $\mathrm{K}$ was applied (Figure $1 \mathrm{a}$ ). The foliar application of $\mathrm{K}$ was also effective under normal and saline environments. The L-check1 hybrid produced the maximum leaf area under normal and saline environments through the foliar supplication of $\mathrm{K}$ as compared with the L-16003 hybrid (Figure 1b). A similar trend was also observed regarding shoot length (Figure 1c). Foliar application $\mathrm{K}$ was more effective regarding root length. The maximum root length was recorded in the L-16003 hybrid even under a saline environment (Figure 1d), while the minimum root length was noted in the L-check1 hybrid under a saline environment. More plant fresh and dry weights were recorded under a normal environment with the foliar application of $\mathrm{K}$ in the L-16003 hybrid (Figure 1e,f). L-check1 hybrid performed better regarding achene weight both under normal or saline environments. The foliar application of $\mathrm{K}$ was also effective regarding achene weight in both environments (Figure 1g). The minimum achene weight was found in the L-check1 hybrid under a saline environment without exogenous treatment. 
Table 1. Mean sum of the squares of growth and the physiological parameters of sunflower hybrids grown under salinity stress environments in response to foliar applied potassium.

\begin{tabular}{|c|c|c|c|c|c|c|c|c|c|c|c|c|c|}
\hline sov & DF & $\begin{array}{c}\text { No of } \\
\text { Leaves }\end{array}$ & Leaf Area & $\begin{array}{c}\text { Shoot } \\
\text { Length }\end{array}$ & $\begin{array}{c}\text { Root } \\
\text { Length }\end{array}$ & $\begin{array}{c}\text { Plant Fresh } \\
\text { Weight }\end{array}$ & $\begin{array}{c}\text { Plant Dry } \\
\text { Weight }\end{array}$ & $\begin{array}{l}\text { Achene } \\
\text { Weight }\end{array}$ & $\begin{array}{c}\text { Stomatal } \\
\text { Conductance }\end{array}$ & $\begin{array}{c}\text { Transpiration } \\
\text { Rate }\end{array}$ & WUE & $\mathrm{CO}_{2} \mathrm{AR}$ & TSP \\
\hline $\begin{array}{l}\text { Salinity } \\
\text { stress (S) }\end{array}$ & 1 & $165^{* *}$ & $1137^{* *}$ & 294 ** & $8.88 * *$ & 19.561 ** & $2.877^{* *}$ & 29.15 ** & $0.018 * *$ & $0.126^{* * *}$ & $5.771^{* *}$ & $0.083^{* *}$ & $1.736 * *$ \\
\hline $\begin{array}{l}\text { Treatment } \\
\text { (T) }\end{array}$ & 1 & $145^{* *}$ & $724^{* *}$ & $77.7^{* *}$ & $9.63 * *$ & $4.182 * *$ & 0.246 ** & $18.71^{* *}$ & 0.026 ** & $0.024 \mathrm{NS}$ & $0.451 \mathrm{NS}$ & 0.0001 NS & $0.045^{\mathrm{NS}}$ \\
\hline Hybrid (H) & 1 & $22.0^{*}$ & $4.86^{\mathrm{NS}}$ & $0.202 \mathrm{NS}$ & $0.24 \mathrm{NS}$ & 0.0072 * & $0.015 \mathrm{NS}$ & $0.782 \mathrm{NS}$ & $0.001 \mathrm{NS}$ & $0.151^{* *}$ & $0.622 \mathrm{NS}$ & $14.56^{* *}$ & $0.0003 \mathrm{NS}$ \\
\hline $\mathrm{S} \times \mathrm{T}$ & 1 & $7.04 \mathrm{NS}$ & $0.47^{\mathrm{NS}}$ & $3.23 \mathrm{NS}$ & $0.202 \mathrm{NS}$ & 0.841 * & $0.049 \mathrm{NS}$ & $0.435 \mathrm{NS}$ & $0.002 \mathrm{NS}$ & $0.028 \mathrm{NS}$ & $1.456 * *$ & $10.73^{* *}$ & $0.688 * *$ \\
\hline $\mathrm{S} \times \mathrm{H}$ & 1 & $22.0^{*}$ & $1.05 \mathrm{NS}$ & $0.04 \mathrm{NS}$ & $0.042 \mathrm{NS}$ & $0.061 \mathrm{NS}$ & $0.004 *$ & $0.234 \mathrm{NS}$ & $0.002 \mathrm{NS}$ & $0.003 \mathrm{NS}$ & $0.002 \mathrm{NS}$ & $0.199 \mathrm{NS}$ & $0.002 \mathrm{NS}$ \\
\hline $\mathrm{T} \times \mathrm{H}$ & 1 & $3.37 \mathrm{NS}$ & $82.2 * *$ & $8.82 \mathrm{NS}$ & $0.007^{\mathrm{NS}}$ & $0.0017^{\mathrm{NS}}$ & $0.0006^{\mathrm{NS}}$ & $3.161 * *$ & $0.003 *$ & $0.004 \mathrm{NS}$ & $0.202 \mathrm{NS}$ & $2.131 \mathrm{NS}$ & $0.034 \mathrm{NS}$ \\
\hline $\mathrm{S} \times \mathrm{T} \times \mathrm{H}$ & 1 & $0.37^{\mathrm{NS}}$ & $0.015^{\mathrm{NS}}$ & $8.40 \mathrm{NS}$ & $0.015^{\mathrm{NS}}$ & $0.0198 \mathrm{NS}$ & $0.00022 \mathrm{NS}$ & $1.607^{*}$ & $0.001 \mathrm{NS}$ & $0.001 \mathrm{NS}$ & $0.261^{\mathrm{NS}}$ & $0.609 \mathrm{NS}$ & $0.006^{\mathrm{NS}}$ \\
\hline
\end{tabular}

SOV-source of variance; DF-degree of freedom; WUE-water use efficiency; AR-assimilation rate; TSP-total soluble proteins;

NS_non-significant; * - significant at $p \leq 0.05 ;{ }^{* *}$ - significant at $p \leq 0.01$.

\subsection{Biochemical and Physiological Attributes}

Biochemical and physiological attributes including stomatal conductance, transpiration rate, water use efficiency, $\mathrm{CO}_{2}$ assimilation rate, total soluble proteins, and chlorophyll $a$ and $b$ contents were significantly affected under a saline environment compared with normal conditions (Tables 1 and 2). The data regarding the stomatal conductance of two sunflower hybrids grown under control and saline environments is presented in Figure $1 \mathrm{~h}$. Saline conditions significantly reduced the stomatal conductance. In the L-16003 hybrid, the maximum reduction in gas exchange attributes was noted under the saline condition when $\mathrm{K}$ was not applied. Conversely, significant results were observed in the L-chek1 hybrid under the non-saline condition with $\mathrm{K}$ application. Salt stress significantly reduced the transpiration rate (Figure 2a). In the L-16003 hybrid, an extreme reduction was observed under the saline condition when $\mathrm{K}$ was not applied. Nevertheless, a less non-significant content was observed under the control conditions with $\mathrm{K}$ application in Line-chek1.

On the other hand, the spray of $\mathrm{K}$ showed non-significant results, but the difference between hybrids was significant. Salt stress reduced the water use efficiency (Figure 2b). Under salinity conditions when $\mathrm{K}$ was not applied, the maximum reduction was noted in Line-16003. Conversely, in the L-chek1 hybrid, the maximum non-significant increase was perceived under the controlconditions. Overall, L-chek1 hybrid performed better than the L-16003 hybrid. A maximum decrease was noted in Line-chek1 under salinity stress when $\mathrm{K}$ was not sprayed. Generally, the spray of K showed non-significant results, but the hybrid difference was significant. The data related to the total soluble protein of two sunflower hybrids tested under the control and salt stress conditions are given in Figure 2d. Salt stress significantly reduced the total soluble protein. In the L-16003 hybrid, the maximum reduction was noted under saline conditions when $\mathrm{K}$ was not applied. Overall, the L-chek1 hybrid performed better than the L-16003 hybrid.

Table 2. Mean sum of squares of biochemical, antioxidants and mineral elements of sunflower hybrids grown under salinity stress environment in response to foliar applied potassium.

\begin{tabular}{|c|c|c|c|c|c|c|c|c|c|c|c|c|c|}
\hline sov & DF & Chl $a$ & Chl $b$ & Phenolics & Carotenoids & Catalase & Peroxidase & Root $\mathrm{Ca}^{2+}$ & Shoot $\mathrm{Ca}^{2+}$ & Root $\mathrm{K}^{+}$ & Shoot $\mathrm{K}^{+}$ & Root $\mathrm{Na}^{+}$ & Shoot $\mathrm{Na}^{+}$ \\
\hline Salinity stress (S) & 1 & $0.004 * *$ & $0.004 * *$ & $0.064^{* *}$ & $1.391^{* *}$ & $4.313^{* *}$ & 0.276 ** & $3.375 \mathrm{NS}$ & $266.7^{* *}$ & $280.2 * *$ & $384 * *$ & $368^{* *}$ & 513 ** \\
\hline Treatment (T) & 1 & $0.009^{* *}$ & $0.043 * *$ & $0.012 * *$ & $1.271 * *$ & $0.792 * *$ & $0.015^{\mathrm{NS}}$ & 22.04 * & $280.7^{* *}$ & $266.7^{* *}$ & $294^{* *}$ & $8.17 \mathrm{NS}$ & 222 ** \\
\hline Hybrid (H) & 1 & $0.001 \mathrm{NS}$ & $0.001 \mathrm{NS}$ & $0.004 \mathrm{NS}$ & $0.014 \mathrm{NS}$ & $0.243^{* *}$ & $0.029 \mathrm{NS}$ & $5.042 \mathrm{NS}$ & $10.67 \mathrm{NS}$ & $8.167^{\mathrm{NS}}$ & $10.67 \mathrm{NS}$ & $37.5^{*}$ & $30.38 *$ \\
\hline $\mathrm{S} \times \mathrm{T}$ & 1 & $0.004 *$ & $0.001 \mathrm{NS}$ & $0.008^{* *}$ & $0.026^{\mathrm{NS}}$ & $0.143 * *$ & $0.001 \mathrm{NS}$ & $3.375 \mathrm{NS}$ & $4.167^{\mathrm{NS}}$ & $2.667 \mathrm{NS}$ & $0.667^{\mathrm{NS}}$ & $28.17 \mathrm{NS}$ & $70.04 * *$ \\
\hline $\mathrm{S} \times \mathrm{H}$ & 1 & $0.006^{\mathrm{NS}}$ & $0.007 \mathrm{NS}$ & $0.001 \mathrm{NS}$ & $0.192 * *$ & $0.282^{* *}$ & $0.035^{\mathrm{NS}}$ & $0.375^{N S}$ & ${ }_{10.67} \mathrm{NS}$ & $13.5^{\mathrm{NS}}$ & $6.01 \mathrm{NS}$ & $8.167 \mathrm{NS}$ & 30.38 * \\
\hline $\mathrm{T} \times \mathrm{H}$ & 1 & $0.007 \mathrm{NS}$ & $0.002 *$ & $0.0062 *$ & $0.029 \mathrm{NS}$ & $0.202 * *$ & $0.001 \mathrm{NS}$ & $0.042 \mathrm{NS}$ & $73.5^{* *}$ & $80.67 * *$ & $10.67^{\mathrm{NS}}$ & $1.5 \mathrm{NS}$ & $0.375 \mathrm{NS}$ \\
\hline $\mathrm{S} \times \mathrm{T} \times \mathrm{H}$ & 1 & $0.008 \mathrm{NS}$ & $0.001 \mathrm{NS}$ & 0.0012 NS & $0.047 \mathrm{NS}$ & $0.145^{* *}$ & 0.002 NS & $0.042 \mathrm{NS}$ & $13.5^{\mathrm{NS}}$ & $16.67 \mathrm{NS}$ & $16.67 *$ & $0.167 \mathrm{NS}$ & $2.042 \mathrm{NS}$ \\
\hline
\end{tabular}

SOV—source of variance; DF—degree of freedom; Chl—chlorophyll; NS—non-significant; * —significant at $p \leq 0.05$; ** significant at $p \leq 0.01$. 


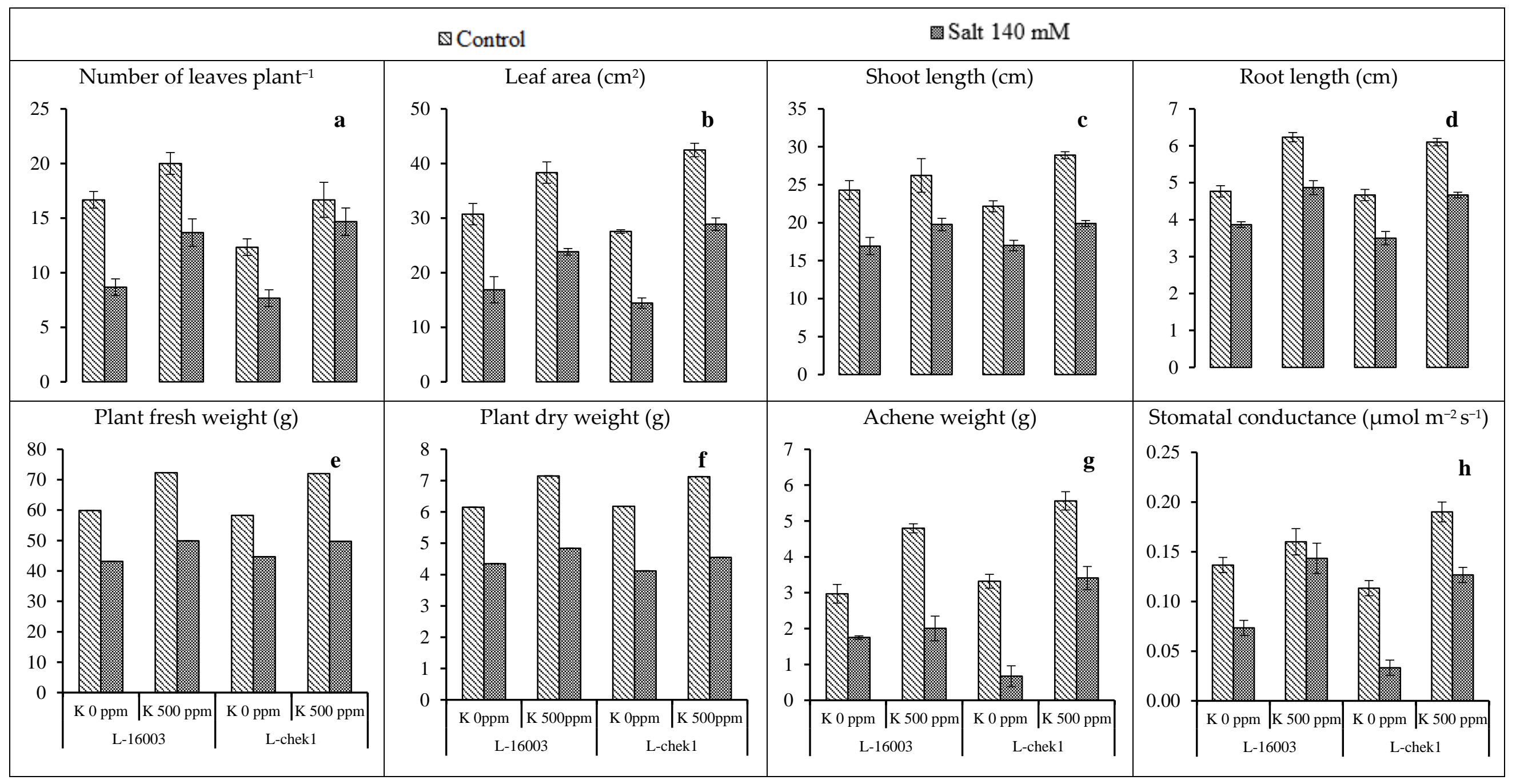

Figure 1. Impact of foliar applied potassium on the number of leaves per plant ${ }^{-1}$ : (a) leaf area, (b) shoot length, (c) root length, (d) plant fresh weight, (e) plant dry weight, (f) achene weight, (g) and stomatal conductance $(\mathbf{h})$ of sunflower hybrids grown under a salinity stress environment. 
$\$$ Control

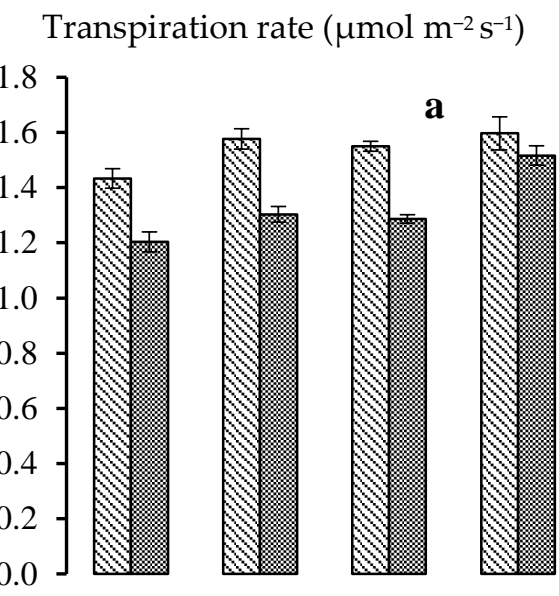

Chlorophyll $a$ contents (mg/g fresh weight)

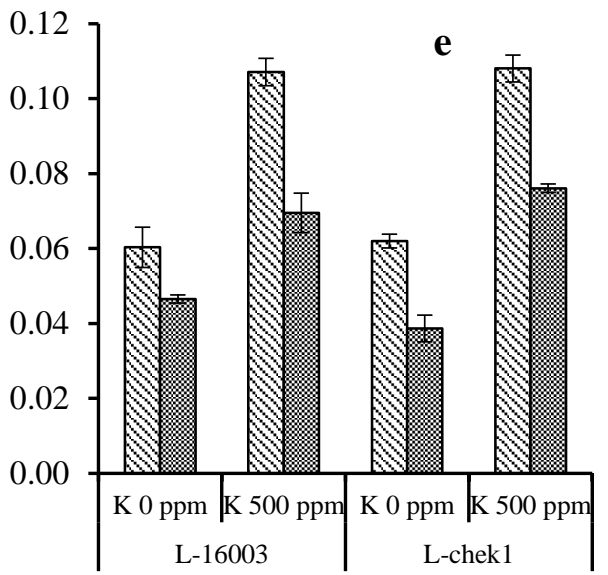

Water use efficiency $\left(\mathrm{umolCO}_{2} / \mathrm{mmol}\right.$ $\left.\mathrm{H}_{2} \mathrm{O}\right)$

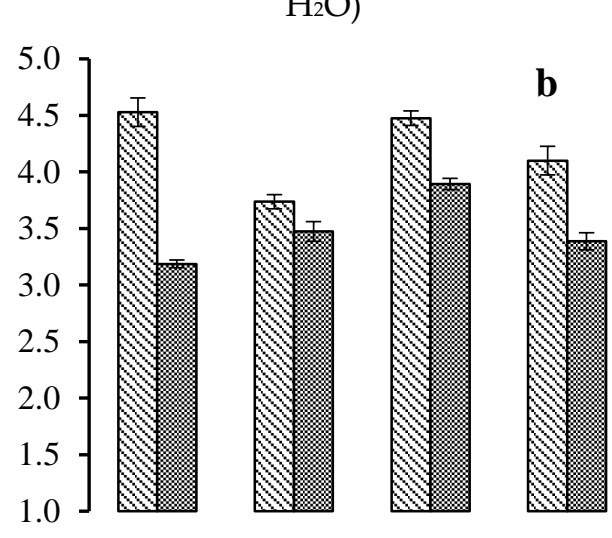

Chlorophyll $b$ contents (mg/g fresh weight)

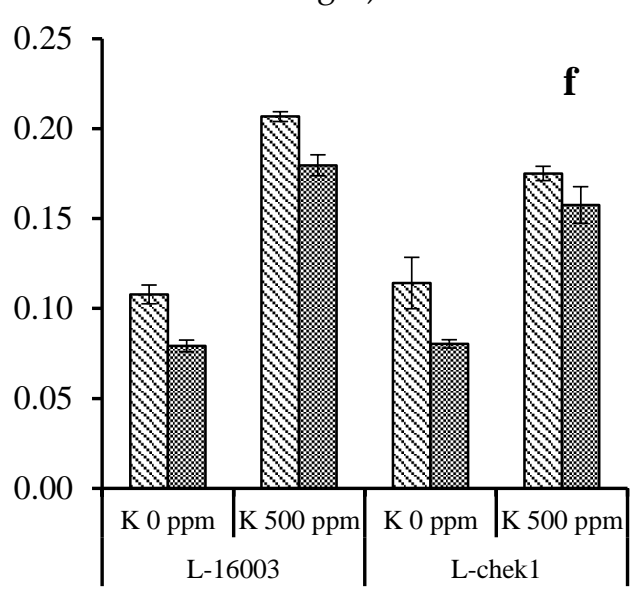

\section{Salt $140 \mathrm{mM}$}

$\mathrm{CO}_{2}$ Assimilation rate $\left(\mu \mathrm{mol} \mathrm{m} \mathrm{m}^{-2} \mathrm{~s}^{-1}\right)$
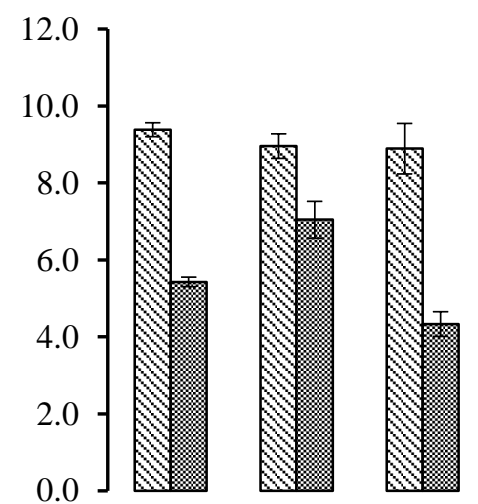

c

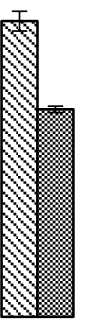

Phenolics (mg/g fresh weight)

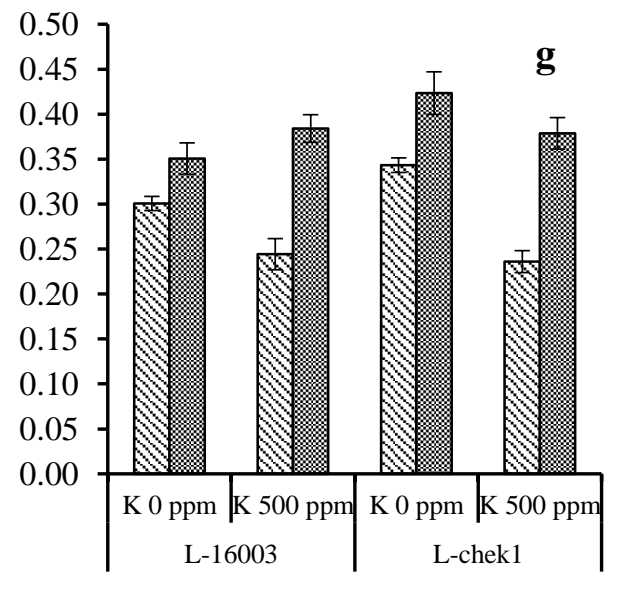

Total soluble proteins (unit/mg fresh weight)

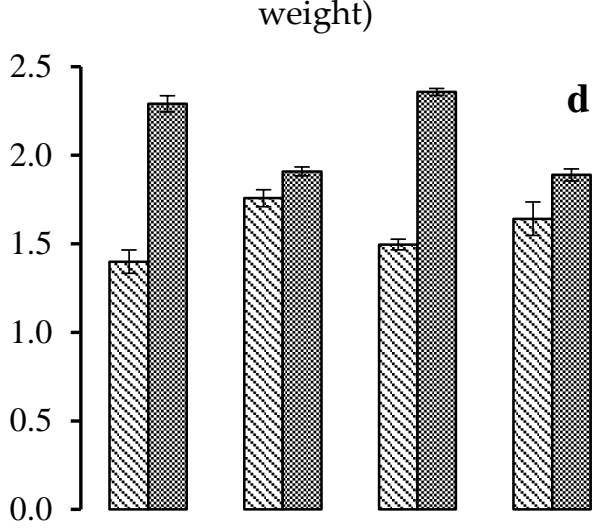

Carotenoids (mg/g fresh weight)

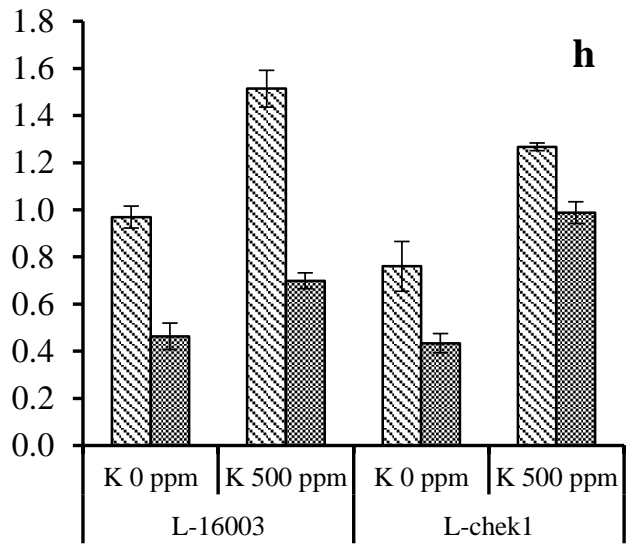

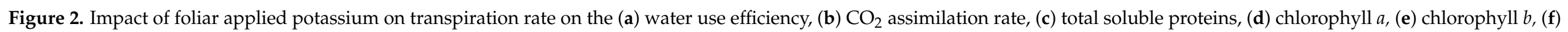
phenolics, (g) and carotenoids (h) of sunflower hybrids grown under a salinity stress environment. 
Data about the chlorophyll $a$ and $b$ contents of the two sunflower hybrids tested under non-saline and salinity stress are presented in Figure 2e,f. In chlorophyll $a$, a significant decrease was reported under saline stress conditions. Under saline stress conditions, when $\mathrm{K}$ was not applied, a maximum reduction was found in the L-16003 hybrid. Conversely, the most significant increase was noted in both hybrids of sunflower under non-saline conditions when $\mathrm{K}$ was applied in the L-chek1 hybrid. The spray of K showed a significant result, but the hybrid difference was observed as being non-significant. Regarding the chlorophyll $b$ contents, a similar trend was observed. Overall, the L-16003 hybrid performed better than the L-chek1 hybrid.

\subsection{Antioxidant and Enzymatic Activities}

The total phenolics and carotenoid concentrations were similar within the hybrids, while they were significantly affected by K application and a saline environment (Table 2). Saline stress indicated a significant rise in phenolic (Figure $2 \mathrm{~g}$ ). The minimum content of phenolic was observed in the L-16003 hybrid under the normal conditions when K was not applied. Under salinity conditions, a maximum increase was observed in the L-chek1 hybrid. Effect of the foliar application of $\mathrm{K}$ was significant in both hybrids. The combination of salt with $\mathrm{K}$ also showed significant results. For instance, the L-chek1 hybrid performed well as compared with the L-16003 hybrid (Figure 2g). Data about the carotenoids of two sunflower hybrids were tested under the control, and the salinity stress situation is reported in Figure 2h. Salinity stress significantly reduced carotenoids. Under saline conditions, more reductions were found in the L-chek1 hybrid. Conversely, a maximum significant increase was seen in the L-16003 hybrid under non-saline conditions when K was applied. Overall, the L-16003 hybrid performed better than the L-chek1 hybrid.

Catalase activities were significantly affected by the foliar application of $\mathrm{K}$ under normal and saline environments, even within the hybrids (Table 2). In contrast, the peroxidase activities were only affected by the saline environment. Under saline stress conditions, when $\mathrm{K}$ was not applied, a maximum rise was seen in the L-16003 hybrid. Under control conditions, a maximum reduction was recorded in the L-chek1 hybrid (Figure 3a). Significant results were observed in the hybrids as a result of foliar applied K. Data regarding the peroxidase of both sunflower hybrids tested under control and salt stress conditions with foliar applied $\mathrm{K}$ are presented in Figure $3 \mathrm{~b}$. The application of salt stress indicated a significant increase in peroxidase activity. In the L-chek1 hybrid, a maximum increase was noted under saline stress conditions when $\mathrm{K}$ was not applied. A maximum reduction was recorded in the L-16003 hybrid under non-saline conditions. Overall, the L-chek1 hybrid achieved better results than the L-16003 hybrid.

\subsection{Mineral Homeostasis}

The root calcium was not significantly affected by the saline environment and even within the hybrids, but foliar application $\mathrm{K}$ significantly affected the concentration of calcium in the roots (Table 2) while the shoot calcium was significantly affected by $\mathrm{K}$ treatment and salinity stress. The root and shoot $\mathrm{K}$ was significantly affected by foliar treatments and salinity stress (Table 2). The root sodium was not significantly affected by the foliar treatment, but were significantly affected within the hybrid and by foliar treatment (Table 2). In contrast, shoot sodium was significantly influenced by salinity stress and foliar treatments even within hybrids (Table 2). Under salinity stress, a non-significant decrease in root $\mathrm{Ca}^{2+}$ was observed (Figure 3c). Under saline conditions, the maximum reduction was examined in L-16003 when K was not applied. Nevertheless, a significant increase was detected in the sunflower L-chek1 under control conditions when $\mathrm{K}$ was applied. Salt stress significantly reduced the root $\mathrm{Ca}^{2+}$ as shown in Figure $3 \mathrm{~d}$. In the L16003 hybrid, the maximum reduction was perceived under the saline stage. A maximum significant increase was examined in the L-chek1 hybrid under the control conditions when the K was applied. Alternatively, the foliar application of K showed significant results, but non-significant results were recorded for the hybrids. 


\section{$\$$ Control}

Catalase (unit/mg protein)

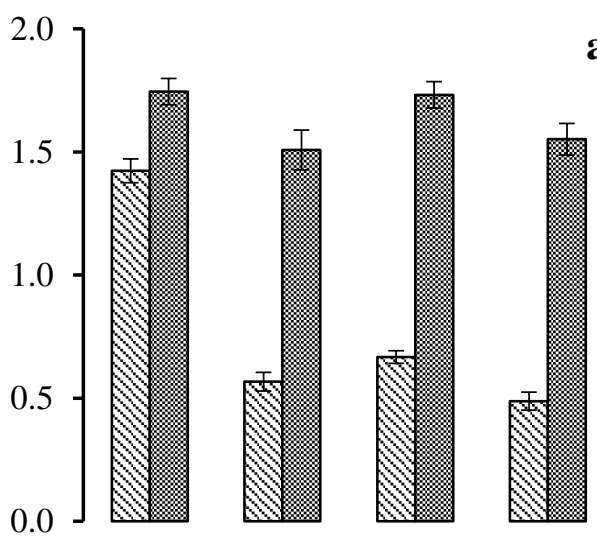

Root $\mathrm{K}^{+}$(mg/g dry weight)

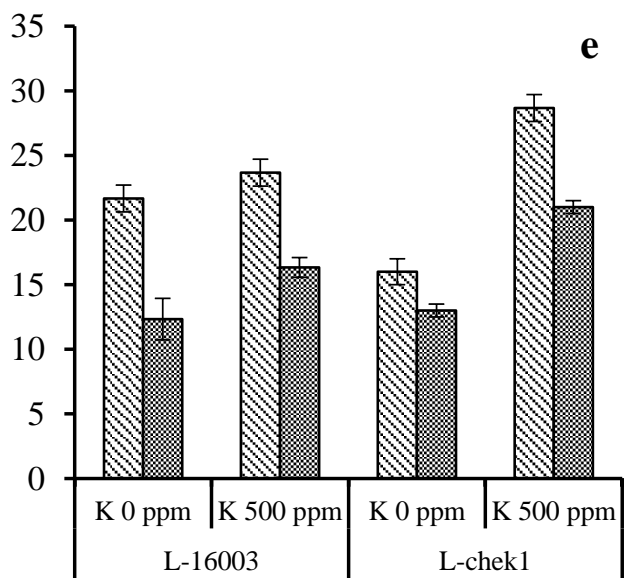

a

Peroxidase (unit/mg protein)

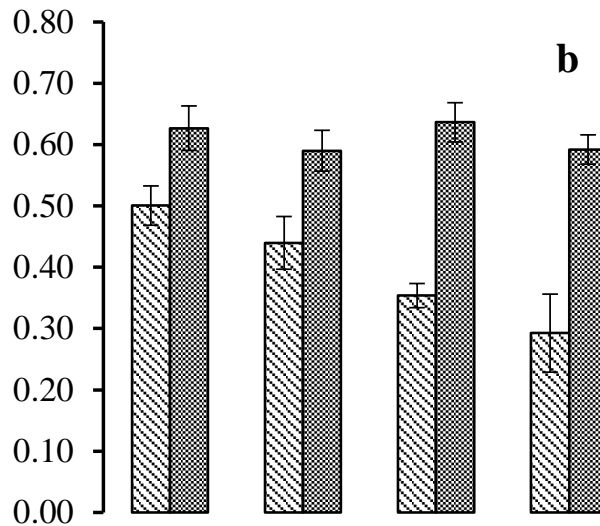

Shoot $\mathrm{K}^{+}$(mg/g dry weight)

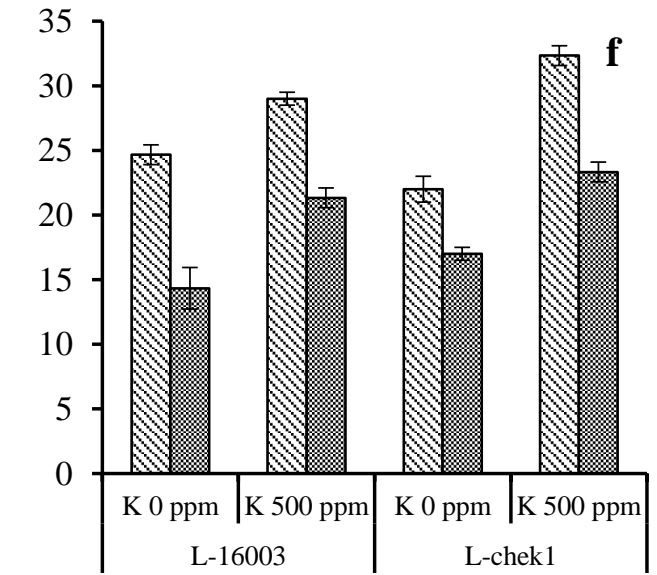

Salt $140 \mathrm{mM}$

Root $\mathrm{Ca}^{2+}(\mathrm{mg} / \mathrm{g}$ dry weight)

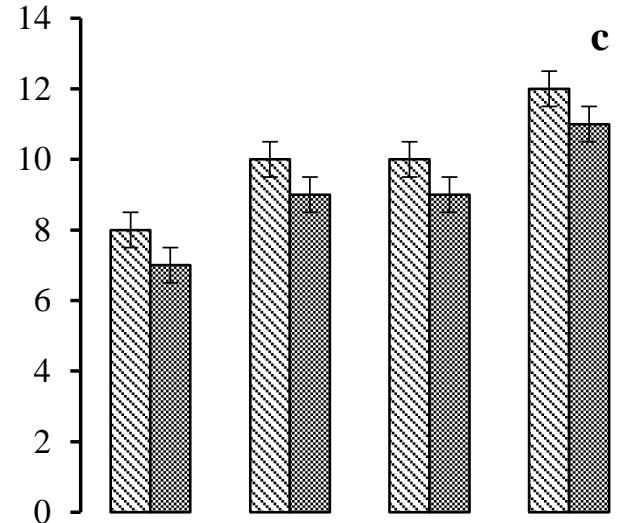

Root $\mathrm{Na}^{+}$(mg/g dry weight)

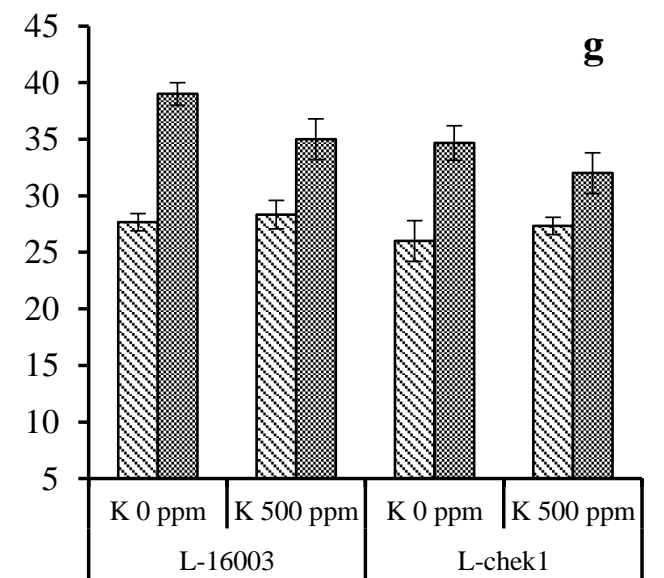

Shoot $\mathrm{Ca}^{2+}$ (mg/g dry weight)

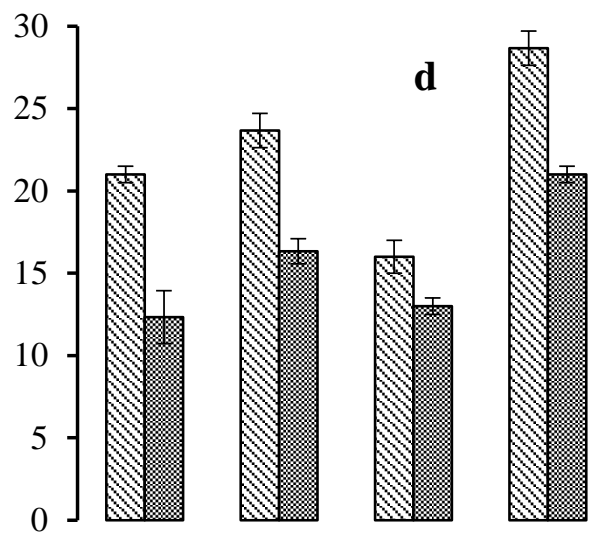

Shoot $\mathrm{Na}^{+}$(mg/g dry weight)

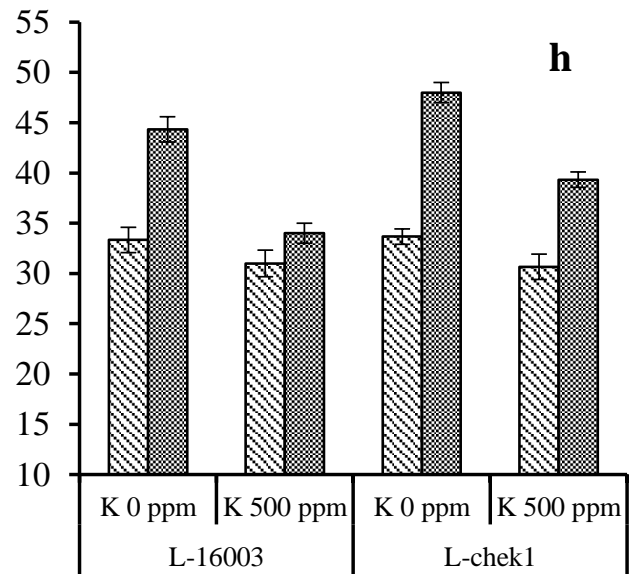

Figure 3. Impact of foliar applied potassium on the catalase (a), peroxidase $(\mathbf{b})$ activities, $\operatorname{root} \mathrm{Ca}^{2+}(\mathbf{c})$, shoot $\mathrm{Ca}^{2+}(\mathbf{d})$, $\operatorname{root} \mathrm{K}^{+}(\mathbf{e})$, shoot $\mathrm{K}^{+}(\mathbf{f})$, $\operatorname{root} \mathrm{Na}^{+}(\mathbf{g})$, and shoot $\mathrm{Na}^{+}(\mathbf{h})$ of sunflower hybrids grown under a salinity stress environment. 
Data relating to root the $\mathrm{K}^{+}$of two sunflower hybrids is indicated in Figure 3e. Salt stress indicated a non-significant reduction in root $\mathrm{K}^{+}$. In the sunflower L-16003 hybrid, a maximum reduction was detected under salt stress when the applied concentration of $K$ was nothing. Overall, the L-chek1 hybrid performed better than the L-16003 hybrid. The shoot $\mathrm{K}^{+}$was decreased significantly by the salt stress (Figure 3f). An extreme reduction was examined in L-16003 under saline conditions without K application. Although a maximum significant rise was observed in the L-chek1 under the control condition when $\mathrm{K}$ was applied as a foliar spray. In other words, the spray of K shows significant results, but non-significant results were recorded regarding the hybrids. The presence of salt stress indicated a significant reduction in root $\mathrm{Na}^{+}$(Figure $3 \mathrm{~g}$ ). Under saline conditions when $\mathrm{K}$ was not applied, a maximum reduction was noted in the sunflower L-chek1 hybrid. Nevertheless, a maximum non-significant increase was observed in L-16003 under nonsaline conditions when $\mathrm{K}$ was applied. Alternatively, the spray of K showed non-significant results but a significant effect regarding hybrids. Overall, L-16003 performed better than the L-chek1 hybrid. Salt stress application triggered a non-significant reduction in the shoot $\mathrm{Na}^{+}$. Under saline conditions, when $\mathrm{K}$ was not applied, a maximum reduction was noted in the L-16003 hybrid. However, a maximum increase was perceived in the L-chek1 under control condition when $\mathrm{K}$ was folairly applied. On the other hand, the spray of $\mathrm{K}$ indicated significant results. K hindered the salt effect. Overall, the L-chek1 hybrid performed better comparatively than the L-16003 hybrid (Figure 3h).

\section{Discussion}

Salinity is a key stress limiting agricultural productivity worldwide. Salinity stress induced the nutritional imbalance and decreased the dry weight production in both hybrids as the present study was planned with aims to improve sunflower growth attributes under salinity stress by exogenously applied macronutrients like K. Salt stress-induced a nutritional imbalance [5] and a reduction of growth and productivity [8] have been observed in amaranth, which corroborated the present findings. The findings of our study were supported by Hussain et al. [42] and Shehzad et al. [18]. The findings of the current study regarding the leaf area, shoot length, and achene weight were in harmony with the outcomes of different crops observed by Latef and Chaoxing [43] on pepper and Mostofa et al. [44] on rice. The reduction effect of salinity stress on plant growth parameters may be due to the toxic effect of $\mathrm{Na}$ and $\mathrm{Cl}$ ions, and their excessive accumulation around the root system and accordingly in plant cells. Kosová et al. [45] explained that these ions reduced the uptake of water by plants resulted from the increased osmotic pressure of soil solution. Rehman et al. [26] and Farooq et al. [46] also repoted that the application of minerals either alone or in combination with growth promoters improved the growth attributes of crops.

Plants overcome the salinity toxic effect via mechanisms of osmotic adjustment (increases the compatible solutes), improved stomata closure, and decreased photosynthesis rates. Foliar applied K enhanced the growth parameters by improving the osmotic adjustment [47]. K sustains the turgidity of the guard cells, opening and closing of the stomata, and maintains water use efficiency [48]. When salt was applied on sunflower replicates, the negative effects were observed as a decrease in leaf area $\left(\mathrm{cm}^{2}\right)$, but when $\mathrm{K}$ was foliar applied, it suppressed the effect of $\mathrm{NaCl}$ as $\mathrm{K}$ inhibited the salt effect. According to Ashfaq et al. [49], $\mathrm{K}$ is an essential macronutrient that improves stress resistance in plants and also plays role in osmotic adjustment. The foliar application of $\mathrm{K}$ by 500 ppm increased various growth attributes like the number of leaves, plant length, leaf area, fresh and dry plant weight, and capitulum size compared with the control. Zaman et al. [16] reported that $\mathrm{K}^{+}$is parallel to $\mathrm{Na}^{+}$, many $\mathrm{K}$ transporters do not distinguish between these cations. Salinity indicated an adverse accumulation of sodium ions in the plant cell. Therefore, the application of $\mathrm{K}$ at a higher concentration is beneficial for the growth of sunflower. Furthermore, the foliar spray of $\mathrm{K}$ also positively adjusts the membrane stability and turgidity of plants under salt stress, that is why plants should be treated with $\mathrm{K}$ in both conditions either in the absence and presence of stress conditions. Raza et al. [15] reported that the 
foliar application of $1 \% \mathrm{~K}$ enhanced all of the parameters relevant to the morphological, physiological, and biochemical processes in sunflower.

Salt stress induces an over production of ROS that elicits DNA damage, inhibition of photosynthesis, lipid peroxidation, reduction in the rate of photosynthesis, and disturbance in the mineral nutrient status [50]. Sodium is the major cation $\left(\mathrm{Na}^{+}\right)$that accumulates mainly in the roots and stems as the salt concentration increases in the rhizosphere [51]. Tabaxi et al. [52] stated that the application of various fertilizers or mineral elements improved the agronomic and quality charateristics of crops. Jan et al. [14] concluded that the valuable macronutrient $\mathrm{K}$ triggers the growth of sunflower, and its yield becomes good because it decreases the transpiration rate and enhances the water uptake. It also prolongs the turgidity and minimizes the adverse effect of reactive oxygen species. In sunflower, $\mathrm{K}$ plays a very important role in salinity tolerance. It increases growth and minimizes the effect of salinity [53]. $\mathrm{K}$ is a good osmoticum and charge carrier in the plant and antagonistic relationship with a sodium uptake. In a saline environment, $\mathrm{K}^{+}$can be used as a metabolite to control the turgor and avoid osmotic shock [54]. It is an essential macro element of plant growth and plays a vital role in several metabolic activities, i.e., the flow of water, nutrients, and carbohydrates in plant tissue. $\mathrm{K}$ can counteract the harmful effect of salinity and maintains the ions' homeostasis. The application of inorganic fertilizers and mineral elements is considered a helpful practice in maintaining the crop productivity with improved soil fertility to achieved the maximum plant growth and economical yield under stressful conditions $[55,56]$.

In the present study, salinity stress enhances the total phenolic contents of sunflower in both hybrids. Interestingly, potassium application also accelerates the augmentation of the total phenolic contents. The literature has shown that plants have both antioxidant enzymes and secondary metabolites and/or non-enzymatic antioxidants, such as phenolics, for example hydroxybenzoic acids [57], hydroxycinnamic acids [58], flavonols [59], flavanols [60], flavanones [61], flavones [62], betalain [63], tocopherols [64], betacyanin [65], ascorbic acids [66], chlorophyll $a$ [67], carotenoids [68], chlorophyll $b$ [69], betaxanthin [70], and beta-carotene [71], with a strong radical scavenging capacity [72]. Nevertheless, for stress homeostasis, abiotic stress-induced plants have evolved mechanisms to enhance the concentration of the majority of secondary metabolites and/or antioxidants $[58,73]$ and detoxify the ROS. Akram et al. [74] applied $150 \mathrm{mM}$ sodium chloride on sunflower, and it influenced the osmotic potential in leaves but significantly enhanced the catalase, superoxide dismutase (SOD), and peroxidase activity. Similarly, salinity stress promotes reactive oxygen species (ROS) accumulation to adversely affect the plant developmental processes [75]. The shoot and root $\mathrm{Ca}^{2+}$ were decreased through the application of salinity stress, and a maximum reduction was examined in L-16003. Salinity increased the uptake of $\mathrm{Na}+$ and reduced $\mathrm{K}+$ and $\mathrm{Ca} 2+$, but the foliar application of $\mathrm{K}$ enhanced the concentration of $\mathrm{K}+$ and $\mathrm{Ca} 2+$ in the root and shoot while it reduced the uptake of $\mathrm{Na}$ under saline conditions (Figure $3 c-h$ ). Our findings are in line with Hurtado et al. [12], who stated that salinity adversely affects the uptake of nutrients in sunflower. The decreased uptake efficiency of nutrients in sunflower plants under salinity stress may have been caused by $\mathrm{Na}^{+}$competing with cations, a process that is associated with toxic effects such as the generation of reactive oxygen species, which can degrade enzymes or nutrient uptake transporters [76].

\section{Conclusions}

The growth, physiological, gas exchange attributes, antioxidants, and $\mathrm{Ca}^{2+}$ and $\mathrm{K}^{+}$ balance were significantly enhanced by the foliar application of $K$ at 500 ppm under a saline environment. A healthy growth of sunflower was also achieved through foliar applied $\mathrm{K}$. Further studies are required to explore the mechanism of $\mathrm{K}$ at a molecular level in sunflower as well as in other field crops. 
Author Contributions: Conceptualization, A.A.-H., S.K. and Z.H.; methodology, A.A.-H., D.I., A.B. and M.A.; software, S.T.R.G., M.A.N. and S.K.; validation, S.K., S.I. and Z.H.; formal analysis, A.A. and D.I.; investigation, A.B. and M.A.N.; writing-original draft preparation, A.A., S.K. and A.T.K.Z.; writing-review and editing, S.K., D.I. and A.B.; supervision, S.K.; funding acquisition, A.A., M.B., M.S. and A.T.K.Z. All authors have read and agreed to the published version of the manuscript.

Funding: This study was supported by Project VEGA 1/0589/19. The authors extend their appreciation to the researchers supporting project number (RSP-2021/219), from King Saud University, Riyadh, Saudi Arabia.

Institutional Review Board Statement: Not applicable.

Informed Consent Statement: Not applicable.

Data Availability Statement: The data that support the outcomes of the current experimentation are available from the corresponding author upon reasonable request.

Acknowledgments: Authors are thankful to the Department of Botany and Department of Agronomy, University of Agriculture, Faisalabad-Pakistan for providing the resources to conduct this experiment. The authors also extend their appreciation to the researchers supporting project number (RSP2021/219), from King Saud University, Riyadh, Saudi Arabia.

Conflicts of Interest: The authors declare no conflict of interest regarding this manuscript.

\section{References}

1. Paul, P.L.C.; Bell, R.W.; Barrett-Lennard, E.G. Variation in the yield of sunflower (Helianthus annuus L.) due to differing tillage systems is associated with variation in solute potential of the soil solution in a salt-affected coastal region of the Ganges Delta. Soil Tillage Res. 2020, 197, 104489. [CrossRef]

2. Hafeez, M.B.; Raza, A.; Zahra, N.; Shaukat, K.; Akram, M.Z.; Iqbal, S.; Basra, S.M.A. Gene regulation in halophytes in conferring salt tolerance. In Handbook of Bioremediation; Elsevier: Amsterdam, The Netherlands, 2021; pp. 341-370.

3. Taher, M.; Beyaz, R.; Javani, M. Morphological and biochemical changes in response to salinity in sunflower (Helianthus annus L.) cultivars. Ital. J. Agron. 2018, 11, 141-147. [CrossRef]

4. Alsaeedi, A.; El-Ramady, H.; Alshaal, T.; El-Garawany, M.; Elhawat, N.; Al-Otaibi, A. Silica nanoparticles boost growth and productivity of cucumber under water deficit and salinity stresses by balancing nutrients uptake. Plant Physiol. Biochem. 2019, 139, 1-10. [CrossRef]

5. Sarker, U.; Oba, S. The Response of Salinity Stress Induced A. tricolor to Growth, Anatomy, Physiology, Non-Enzymatic and Enzymatic Antioxidants. Front. Plant Sci. 2020, 11, 559876. [CrossRef]

6. Sarker, U.; Oba, S. Catalase, superoxide dismutase and ascorbate-glutathione cycle enzymes confer drought tolerance of Amaranthus tricolor. Sci. Rep. 2018, 8, 16496. [CrossRef] [PubMed]

7. Sarker, U.; Oba, S. Drought Stress Effects on Growth, ROS Markers, Compatible Solutes, Phenolics, Flavonoids, and Antioxidant Activity in Amaranthus tricolor. Appl. Biolchem. Biotechnol. 2018, 186, 999-1016. [CrossRef] [PubMed]

8. Sarker, U.; Oba, S. Salinity stress enhances color parameters, bioactive leaf pigments, vitamins, polyphenols, flavonoids and antioxidant activity in selected Amaranthus leafy vegetables. J. Sci. Food Agric. 2019, 99, 2275-2284. [CrossRef]

9. Sarker, U.; Oba, S. Response of nutrients, minerals, antioxidant leaf pigments, vitamins, polyphenol, flavonoid and antioxidant activity in selected vegetable amaranth under four soil water content. Food Chem. 2018, 252, 72-83. [CrossRef]

10. Sarker, U.; Oba, S. Drought stress enhances nutritional and bioactive compounds, phenolic acids and antioxidant capacity of Amaranthus leafy vegetable. BMC Plant Biol. 2018, 18, 258. [CrossRef] [PubMed]

11. Sarker, U.; Islam, M.T.; Oba, S. Salinity stress accelerates nutrients, dietary fiber, minerals, phytochemicals and antioxidant activity in Amaranthus tricolor leaves. PLoS ONE 2018, 13, e0206388. [CrossRef]

12. Hurtado, A.C.; Chiconato, D.A.; de Mello, P.R. Silicon attenuates sodium toxicity by improving nutritional efficiency in sorghum and sunflower plants. Plant. Physiol. Biochem. 2019, 142, 224-233. [CrossRef] [PubMed]

13. Ramadan, A.A.; Abd Elhamid, E.M.; Sadak, M.S. Comparative study for the effect of arginine and sodium nitroprusside on sunflower plants grown under salinity stress conditions. Bull. Natl. Res. Centre 2019, 43, 1-18. [CrossRef]

14. Jan, A.U.; Hadi, F.; Akbar, F. Role of potassium, zinc and gibberellic acid in increasing drought stress tolerance in sunflower (helianthus annuus 1.). Pak. J. Bot. 2019, 51, 809-815. [CrossRef]

15. Raza, M.A.S.; Saleem, M.F.; Khan, I.H. Amelioration in growth and physiological efficiency of sunflower (Helianthus annuus L.) under drought by potassium application. Commun. Soil Sci. Plant Anal. 2018, 49, 2291-2300. [CrossRef]

16. Zaman, B.U.; Ali, A.; Arshadullah, M. Growth Response of Sunflower to Potassium Sulphate Application in Saline-sodic Soil. Asian J. Res. Agric. For. 2018, 1, 1-7.

17. Wada, S.; Takagi, D.; Miyake, C. Responses of the photosynthetic electron transport reactions stimulate the oxidation of the reaction center chlorophyll of photosystem I, p700, under drought and high temperatures in rice. Int. J. Mol. Sci. 2019, 20, 2068. [CrossRef] [PubMed] 
18. Shehzad, M.A.; Fahim, N.; Fiaz, A. Protective effect of potassium and chitosan supply on growth, physiological processes and antioxidative machinery in sunflower (Helianthus annuus L.) under drought stress. Ecotox. Environ. Saf. 2020, 187, 1-11. [CrossRef]

19. Cui, Y.N.; Xia, Z.R.; Ma, Q. The synergistic effects of sodium and potassium on the xerophyte Apocynum venetum in response to drought stress. Plant Physiol. Biochem. 2019, 135, 489-498. [CrossRef]

20. Zamani, S.; Naderi, M.R.; Soleymani, A. Sunflower (Helianthus annuus L.) biochemical properties and seed components affected by potassium fertilization under drought conditions. Ecotox. Environ. Saf. 2020, 190, 11-17. [CrossRef]

21. F.A.O. Statistical Year Book; Food and Agriculture Organization of United Nations: Rome, Italy, 2013.

22. Aishwarya, S.; Anisha, V. Nutritional composition of sunflower seeds flour and nutritive value of products prepared by incorporating sunflower seeds flour. Int. J. Pharm. Res. Allied Sci. 2014, 3, 45-49.

23. Economic Survey of Pakistan, 2020-2021. Available online: https://www.finance.gov.pk/survey/chapters_21/02-Agriculture.pdf (accessed on 11 September 2021).

24. Wu, H.; Zhang, X.; Giraldo, J.P. It is not all about sodium: Revealing tissue specificity and signalling roles of potassium in plant responses to salt stress. Plant Soil. 2018, 431,1-17. [CrossRef]

25. Deinlein, U.; Stephan, A.B.; Horie, T.; Luo, W.; Xu, G.; Schroeder, J. Plant salt-tolerance mechanisms. Trends Plant Sci. 2014, 19, 371-379. [CrossRef]

26. Rehman, A.; Hassan, F.; Qamar, R.; Rehman, A.U. Application of plant growth promoters on sugarcane (Saccharum officinarum L.) budchip under subtropical conditions. Asian J. Agric. Biol. 2021, 2, 202003202. [CrossRef]

27. Makawita, G.I.P.S.; Wickramasinghe, I.; Wijesekara, I. Using brown seaweed as a biofertilizer in the crop management industry and assessing the nutrient upliftment of crops. Asian J. Agric. Biol. 2021. [CrossRef]

28. Hussain, M.U.; Saleem, M.F.; Hafeez, M.B.; Khan, S.; Hussain, S.; Ahmad, N.; Ramzan, Y.; Nadeem, M. Impact of soil applied humic acid, zinc and boron supplementation on the growth, yield and zinc translocation in winter wheat. Asian J. Agric. Biol. 2021. [CrossRef]

29. Anwar, Z.; Basharat, Z.; Hafeez, M.B.; Khan, S.; Zahra, N.; Rafique, Z.; Maqsood, M. Biofortification of Maize with Zinc and Iron not only Enhances Crop Growth but also Improves Grain Quality. Asian J. Agric. Biol. 2021. [CrossRef]

30. Khan, S.; Basit, A.; Hafeez, M.B.; Irshad, S.; Bashir, S.; Bashir, S.; Maqbool, M.M.; Saddiq, M.S.; Hasnain, Z.; Aljuaid, B.S.; et al . Moringa leaf extract improves biochemical attributes, yield and grain quality of rice (Oryza sativa L.) under drought stress. PLoS ONE 2021, 16, e0254452. [CrossRef] [PubMed]

31. Khan, S.; Basra, S.M.A.; Nawaz, M.; Hussain, I.; Foidl, N. Combined application of moringa leaf extract and chemical growthpromoters enhances the plant growth and productivity of wheat crop (Triticum aestivum L.). S. Afri. J. Bot. 2020, 129, 74-81. [CrossRef]

32. Khan, S.; Basra, S.M.A.; Afzal, I.; Nawaz, M.; Rehman, H.U. Growth promoting potential of fresh and stored Moringa oleifera leaf extracts in improving seedling vigor, growth and productivity of wheat crop. Environ. Sci. Pollut. Res. 2017, 24, 27601-27612. [CrossRef] [PubMed]

33. Tamme, A.A.; Kerr, K.L.; Donovan, L.A. Vigour/tolerance trade-off in cultivated sunflower (Helianthus annuus) response to salinity stress is linked to leaf elemental composition. J. Agron. Crop Sci. 2019, 5, 508-518. [CrossRef]

34. Nachabe, M.H. Refining the definition of field capacity in the literature. J. Irrig. Drain. Eng. 1998, 124, 230-232. [CrossRef]

35. Arnon, D.I. Copper enzyme polyphenoloxides in isolated chloroplast in Beta vulgaris. Plant Physiol. 1949, 24, 1-15. [CrossRef] [PubMed]

36. Julkkenon, R. Phenolics constituents in the leaves of northern willows methods for analysis of certain phenolics. Agric. Food Chem. 1985, 33, 213-217.

37. USDA Laboratory Staff. Diagnosis and improvement of saline and alkali soils. In Superintendent of Documents; Richards, L.A., Ed.; U. S. Government Printing Office Washington: Washington, DC, USA, 1954.

38. Chance, B.; Maehly, A.C. Assay of catalaseand peroxidase. Methods Enzymol. 1955, 2, 764-775.

39. Bradford, M.M. A rapid and sensitive method for quantitation or microgram quantities of protein nitiling the principle protein dychinding. Anal. Biochem. 1976, 72, 248-254. [CrossRef]

40. Long, S.P.; Farage, P.K.; Garcia, R.L. Measurement of leaf and canopy photosynthetic $\mathrm{CO}_{2}$ exchange in the field. J. Exp. Bot. 1996, 47, 1629-1642. [CrossRef]

41. Steel, R.G.D.; Torrie, J.H.; Dickey, D.A. Principles and Procedures of Statistics: A Biometrical Approach, 3rd ed.; Mc Graw Hill Book Co. Inc.: New York, NY, USA, 1997; Volume 3, pp. 336-352.

42. Hussain, R.A.; Ashraf, M.Y.; Ahmad, R. Foliar nitrogen and potassium applications improve photosynthetic activities and water relations in sunflower under moisture deficit condition. Pak. J. Bot. 2016, 48, 1805-1811.

43. Latef, A.A.A.; Chaoxing, H. Does the inoculation with Glomus mosseae improves salt tolerance in pepper plants? J. Plant Growth Regul. 2014, 33, 644-653. [CrossRef]

44. Mostofa, M.G.; Fujita, M.; Tran, L.S.P. Nitric oxide mediates hydrogen peroxideand salicylic acid induced salt tolerance in rice (Oryza sativa L.) seedlings. Plant Growth Regul. 2015, 77, 265-277. [CrossRef]

45. Kosová, K.; Vítámvás, P.; Prášil, I.T. Plant proteome changes under abiotic stress—contribution of proteomics studies to understanding plant stress response. J. Proteom. 2011, 74, 1301-1322. [CrossRef]

46. Farooq, O.; Ali, M.; Sarwar, N.; Rehman, A.; Iqbal, M.M.; Naz, T.; Asghar, M.; Ehsan, F.; Nasir, M.; Hussain, Q.M.; et al. Foliar applied brassica water extract improves the seedling development of wheat and chickpea. Asian J. Agric. Biol. 2021. [CrossRef] 
47. Raza, M.A.S.; Saleem, M.F.; Shah, G.M. Exogenous application of glycinebetaine and potassium for improving water relations and grain yield of wheat under drought. J. Soil Sci. Plant Nutr. 2014, 14, 348-364. [CrossRef]

48. Waraich, E.A.; Ahmad, R.; Ashraf, M.Y. Improving agricultural water use efficiency by nutrients management. Acta. Agric. Scand. Soil. Plant. Sci. 2011, 61, 291-304.

49. Ashfaq, A.; Hussain, N.; Athar, M. Role of potassium fertilizers in plant growth, crop yield and quality fiber production of cotton. Fuuast. J. Biol. 2015, 5, 27-35.

50. Nazar, R.; Iqbal, N.; Syeed, S. Salicylic acid alleviates decreases in photosynthesis under salt stress by enhancing nitrogen and sulfur assimilation and antioxidant metabolism differentially in two mungbean cultivars. J. Plant Physiol. 2011, 168, 807-815. [CrossRef] [PubMed]

51. Netondo, G.W.; Onyango, J.C.; Beck, E. Sorghum and salinity: Response of growth, water relations and ion accumulation to NaCl salinity. Crop Sci. 2004, 44, 797-805. [CrossRef]

52. Tabaxi, I.; Zisi, C.; Karydogianni, S.; Folina, A.E.; Kakabouki, I.; Kalivas, A.; Bilalis, D. Effect of organic fertilization on quality and yield of oriental tobacco (Nicotiana tabacum L.) under Mediterranean conditions. Asian J. Agric. Biol. 2021. [CrossRef]

53. Safaa, R.; Magdi, T.; Abde, H. Effect of Potassium Application on Wheat (Triticum aestivum L.) Cultivars grown under salinity stress. World Appl. Sci. J. 2013, 26, 840-850.

54. Kabir, E.; Karimand, M.A.; Azad, M.A.K. Effect of Potassium on salinity tolerance of mungbean. J. Biol. Sci. 2004, 4, 103-110.

55. Zahid, N.; Ahmed, M.J.; Tahir, M.M.; Maqbool, M.; Shah, S.Z.A.; Hussain, S.J.; Khaliq, A.; Rehmani, M.I.A. Integrated effect of urea and poultry manure on growth, yield and postharvest quality of cucumber (Cucumis sativus L.). Asian J. Agric. Biol. 2021. [CrossRef]

56. Safdar, M.E.; Aslam, A.; Qamar, R.; Ali, A.; Javaid, M.M.; Hayyat, M.S.; Raza, A. Allelopathic effect of prickly chaff flower (Achyranthes aspera L.) used as a tool for managing noxious weeds. Asian J. Agric. Biol. 2021, 10. [CrossRef]

57. Sarker, U.; Oba, S. Antioxidant constituents of three selected red and green color Amaranthus leafy vegetable. Sci. Rep. 2019, 9, 18233. [CrossRef]

58. Sarker, U.; Oba, S. Augmentation of leaf color parameters, pigments, vitamins, phenolic acids, flavonoids and antioxidant activity in selected Amaranthus tricolor under salinity stress. Sci. Rep. 2018, 8, 12349. [CrossRef]

59. Sarker, U.; Hossain, M.N.; Iqbal, M.A.; Oba, S. Bioactive Components and Radical Scavenging Activity in Selected Advance Lines of Salt-Tolerant Vegetable Amaranth. Front. Nutr. 2020, 7, 587257. [CrossRef] [PubMed]

60. Sarker, U.; Oba, S. Nutraceuticals, phytochemicals, and radical quenching ability of selected drought tolerant advance lines of vegetable amaranth. BMC Plant Biol. 2020, 20, 564. [CrossRef] [PubMed]

61. Sarker, U.; Oba, S. Polyphenol and flavonoid profiles and radical scavenging activity in leafy vegetable Amaranthus gangeticus. BMC Plant Biol. 2020, 20, 499. [CrossRef]

62. Sarker, U.; Oba, S. Phenolic profiles and antioxidant activities in selected drought tolerant leafy vegetable amaranth. Sci. Rep. 2020, 10, 18287. [CrossRef] [PubMed]

63. Sarker, U.; Oba, S. Color attributes, betacyanin, and carotenoid profiles, bioactive components, and radical quenching capacity in selected Amaranthus gangeticus leafy vegetables. Sci. Rep. 2021, 11, 11559. [CrossRef]

64. Sarker, U.; Oba, S. Nutritional and bioactive constituents and scavenging capacity of radicals in Amaranthus hypochondriacus. Sci. Rep. 2020, 10, 19962. [CrossRef]

65. Sarker, U.; Hossain, M.M.; Oba, S. Nutritional and antioxidant components and antioxidant capacity in green morph Amaranthus leafy vegetable. Sci. Rep. 2020, 10, 1336. [CrossRef]

66. Sarker, U.; Oba, S. Nutrients, minerals, pigments, phytochemicals, and radical scavenging activity in Amaranthus blitum leafy vegetables. Sci. Rep. 2020, 10, 3868. [CrossRef]

67. Sarker, U.; Oba, S. Protein, dietary fiber, minerals, antioxidant pigments and phytochemicals, and antioxidant activity in selected red morph Amaranthus leafy vegetable. PLoS ONE 2019, 14, e0222517. [CrossRef] [PubMed]

68. Sarker, U.; Oba, S. Leaf pigmentation, its profiles and radical scavenging activity in selected Amaranthus tricolor leafy vegetables. Sci. Rep. 2020, 10, 18617. [CrossRef] [PubMed]

69. Sarker, U.; Islam, M.T.; Rabbani, M.G.; Oba, S. Antioxidant Leaf Pigments and Variability in Vegetable Amaranth. Genetika 2018, 50, 209-220. [CrossRef]

70. Sarker, U.; Oba, S. Nutraceuticals, antioxidant pigments, and phytochemicals in the leaves of Amaranthus spinosus and Amaranthus viridis weedy species. Sci. Rep. 2019, 9, 20413. [CrossRef]

71. Sarker, U.; Islam, M.T.; Rabbani, M.G.; Oba, S. Variability in total antioxidant capacity, antioxidant leaf pigments and foliage yield of vegetable amaranth. J. Integ. Agric. 2018, 17, 1145-1153. [CrossRef]

72. Sarker, U.; Oba, S.; Daramy, M.A. Nutrients, minerals, antioxidant pigments and phytochemicals, and antioxidant capacity of the leaves of stem amaranth. Sci. Rep. 2020, 10, 3892. [CrossRef]

73. Sarker, U.; Islam, M.T.; Rabbani, M.G.; Oba, S. Phenotypic divergence in vegetable amaranth for total antioxidant capacity, antioxidant profile, dietary fiber, nutritional and agronomic traits. Acta Agric. Scand. Sect. B Soil Plant Sci. 2018, 68, 67-76. [CrossRef]

74. Akram, A.N.; Ashraf, M.; Al-Qurainyc, F. Aminolevulinic acid-induced changes in somekey physiological attributes and activities of antioxidant enzymes in sunflower (Helianthus annuus L.) plants under saline regimes. Sci. Hortic. 2012, 142, 143-148. [CrossRef] 
75. Luo, X.; Dai, Y.; Zheng, C.; Yang, Y.; Chen, W.; Wang, Q.; Chandrasekaran, U.; Du, J.; Liu, W.; Shu, K. The ABI4-RbohD/VTC2 regulatory module promotes reactiveoxygen species (ROS) accumulation to decrease seed germination under salinity stress. New Phytol. 2021, 229, 950-962. [CrossRef]

76. Santos, C.V. Regulation of chlorophyll biosynthesis and degradation by salt stress in sunflower leaves. Sci. Hortic. 2014, 103, 93-99. [CrossRef] 